\title{
EKSISTENSI OMBUDSMAN REPUBLIK INDONESIA
}

\author{
Yusnani Hasjimzoem \\ Fakultas Hukum Universitas Lampung
}

\begin{abstract}
Republic of Indonesia is a rule of law under Article 1 (3) of the 1945 Constitution and should uphold respect for the rights of individuals and communities in implementing the country. The rights strengthened by the basic norms that become the main spirit of the people of Indonesia, Pancasila. Basic norms that the political objectives in developing the Indonesian nation and enact any bill. Thus the state agency that was created by a special law should work in line with the basic norms of the nation and work together to create prosperity. In 2003 the Ombudsman created by a special law has the duty and function to oversee public services effectively, efficiently, and in spite of the practice of (corruption, collusion, and nepotism). Ombudsman based its duties and functions that have the same vision as mandated in the fourth paragraph of the preamble of the Constitution of 1945. The Ombudsman is thus expected to make a good bureaucratic reform so that it can be a model and public services watchdog whose presence is really felt by the people of Indonesia.
\end{abstract}

Keywords: Ombudsman of the Republic of Indonesia

\section{abstrak}

Republik Indonesia merupakan negara hukum berdasarkan Pasal 1 ayat (3) UUD 1945 sehingga harus menjunjung tinggi penghormatan terhadap hakhak individu dan masyarakat dalam menjalankan penyelenggaraan negara. Hak tersebut diperkuat dengan adanya norma dasar yang menjadi spirit utama dari bangsa Indonesia, yaitu Pancasila. Norma Dasar tersebut yang menjadi tujuan politik Bangsa Indonesia dalam menyusun dan mengundangkan setiap rancangan undang-undang. Dengan demikian lembaga negara yang diciptakan dengan undang-undang khusus harus bekerja senada dengan norma dasar bangsa dan bekerja untuk menciptakan kesejahteraan bersama. Pada tahun 2003 Lembaga Ombudsman yang diciptakan dengan undang-undang khusus memiliki tugas dan fungsi untuk mengawal proses pelayanan publik yang efektif, efisien, dan terlepas dari praktek KKN (Korupsi, Kolusi, dan Nepotisme). Ombudsman berdasarkan tugas dan fungsinya tersebut memiliki visi yang sama sesuai dengan yang diamanatkan pada alinea keempat Pembukaan UUD Tahun 1945. Ombudsman dengan demikian diharapkan dapat membuat reformasi birokrasi yang baik sehingga bisa menjadi teladan sekaligus pengawas 
pelayanan publik yang keberadaannya benar-benar dirasakan oleh masyarakat Indonesia.

\section{Kata Kunci: Ombudsman Republik Indonesia}

\section{A. Pendahuluan}

Dalam perkembangan sejarah, teori dan pemikiran tentang pengorganisasian kekuasaan dan tentang organisasi negara berkembang sangat pesat. Variasi struktur dan fungsi organisasi dan institusi-institusi kenegaraan itu berkembang dalam banyak ragam dan bentuknya, baik di tingkat pusat atau nasional maupun di tingkat daerah atau lokal ${ }^{1}$.

Demikian juga di Indonesia, pasca reformasi 1998, keberadaan lembaga-lembaga independen bertumbuhan baik yang keberadaannya atas perintah UUD 1945 seperti KPU, KY ataupun yang disebabkan oleh perintah undang-undang saja seperti $\mathrm{KI}^{2}$, Ombudsman.

Banyaknya lembaga negara di Indonesia terkadang juga membuat masyarakat menjadi acuh tak acuh melihat keberadaan lembaga-lembaga negara ini. Lembaga negara yang tidak memiliki andil yang efektif sudah sepatutnya dibubarkan saja daripada menghabiskan anggaran negara. Ketidakefektifan juga dapat disebabkan karena adanya faktor penghalang internal dari lembaga tersebut, seperti sumber daya manusia yang kurang bertanggung jawab dan tidak menjalankan tugas dan fungsinya sebagai mestinya. ${ }^{3}$ Dalam bukunya Donald Black menyatakan bahwa: ${ }^{4}$

"Every theory explains deviant behavior with the conditions that motivate an individual to deviate (Berbagai teori menjelaskan bahwa kondisi yang memungkinkan terjadinya perilaku menyimpang)".

Berdasarkan pernyataan Black tersebut dapat dikatakan bahwa kondisi tertentu yang ada dalam suatu lembaga dapat memungkinkan sumber daya manusia dalam suatu lembaga menyimpang tidak sesuai dengan standar operasional di lembaga tersebut. Hal ini menjelaskan bahwa adanya celah yang membuat sumber daya manusia Ombudsman melakukan penyimpangan. Dalam tulisan ini khusus akan dibahas mengenai Lembaga

1 Jimly Asshidiqie, Perkembangan dan Konsolidasi Lembaga Negara Pasca Reformasi, (Jakarta: Sinar Grafika, 2012), hlm. 1.

${ }^{2}$ Keberadaan KI karena perintah UU No. 14 tahun 2008 tentang Keterbukaan Informasi Publik

${ }^{3}$ Kajian mengenai kurang optimalnya lembaga negara independen khususnya di daerah dapat dibandingkan dengan uraian Mustafa Lutfi dan M.Iwan Satriawan, Meneropong Komisi Informasi Publik, (Malang: UB Press, 2014), hlm. 57-103.

${ }^{4}$ Black, Donald, The Behavior of Law, London: Academic Press, 1976, hlm. 99. 
Ombudsman ${ }^{5}$ yang menurut penulis masih belum sesuai dengan cita hukum di undang-undang Ombudsman. Pengkajian mengenai keberadaan Lembaga Ombudsman ini tidak lain dan tidak bukan sebagai wujud penguatan tujuan dibentuknya lembaga tersebut secara hakiki.

Banyak terjadi ketidakadilan dilakukan oleh lembaga pemerintahan masyarakat yang akhirnya membuat masyarakat tidak merasakan penghormatan terhadap hak-hak mereka. Dengan demikian melihat maksud dan tujuan Lembaga Ombudsman memberikan perlindungan dan advokasi terhadap masyarakat menjadi suatu hal penting dan urgent karena berdasarkan Pasal 1 ayat (3) UUD NRI Tahun 1945 Negara Republik Indonesia merupakan Negara Hukum sehingga seharusnya menjunjung tinggi hak-hak individu dan masyarakat.

Dalam menjalani tugasnya Lembaga Ombudsman mengacu pada Pasal 4 Undang-Undang No. 37 Tahun 2008 tentang Ombudsman Republik Indonesia bekerja harus berdasarkan laporan dari masyarakat untuk menelusuri suatu permasalahan pelayanan ataupun ketidakberesan suatu lembaga pelayanan publik ataupun lembaga hukum yang melakukan maladministrasi bagi masyarakat. Maladministrasi adalah perilaku atau perbuatan melawan hukum, melampaui wewenang, menggunakan wewenang untuk tujuan lain dari yang menjadi tujuan wewenang tersebut, termasuk kelalaian atau pengabaian kewajiban hukum dalam penyelenggaraan pelayanan publik yang dilakukan oleh penyelenggara negara dan pemerintahan yang menimbulkan kerugian materiil dan/atau immaterial bagi masyarakat dan orang perseorangan.

Permasalahan mengenai perbuatan mal administrasi tersebut dapat diberantas secara efektif apabila Lembaga Ombudsman mendapatkan laporan dari masyarakat dan jika tidak menerima maka Ombudsman bersifat pasif. Pasal 7 huruf d juga memberikan kewenangan untuk melakukan investigasi pelayanan publik berdasarkan prakarsa sendiri, tetapi langkah ini mungkin tidak populer dengan dibuktikan tidak adanya suatu publikasi yang jelas di media sehingga Ombudsman lebih terlihat kinerjanya dan lebih membumi.

Permasalahan selanjutnya ketika ada laporan dan suatu penindakan oleh Lembaga Ombudsman tersebut apakah lembaga yang diawasi dan diperingatkan oleh Ombudsman akan segera mengubah sistem kerjanya atau

\footnotetext{
${ }^{5}$ Ombudsman menurut pasal 1 ayat (1) UU 37 Tahun 2008 adalah lembaga negara yang mempunyai kewenangan mengawasi penyelenggaraan pelayanan publik baik yang diselenggarakan oleh negara dan pemerintahan termasuk yang diselenggarakan oleh Badan usaha Milik Negara, badan Usaha Milik Daerah, dan Badan Hukum Milik negara serta badan swasta atau perseorangan yang diberi tugas menyelenggarakan pelayanan publik tertentu yang sebagian atau seluruh dananya bersumber dari anggaran pendapatan dan belanja negara dan/ atau anggaran pendapatan dan belanja daerah.
} 
tidak. Masih belum jelasnya sanksi hukum terhadap suatu lembaga yang mendapat perhatian dari Lembaga Ombudsman sehingga tidak memiliki kekuatan hukum mengikat terhadap lembaga yang menerima rekomendasi dari Ombudsman dan tidak mengindahkan. Permasalahannya Lembaga Ombudsman ketika mengkritisi suatu lembaga pelayanan publik hanya akan memberikan rekomendasi kepada lembaga tersebut yang tindak lanjutnya kembali pada iktikad baik lembaga tersebut juga.

Hal itu dapat membuat suatu pemikiran bahwa Ombudsman kurang populer keberadaannya karena tidak memiliki kewenangan dan rekomendasi yang berpengaruh. Sanksi yang dapat diberikan oleh Ombudsman ketika suatu lembaga pelayanan publik tidak mengindahkan rekomendasi dari Ombudsman berdasarkan Pasal 39 Undang-Undang No. 37 Tahun 2008 tentang Ombudsman Republik Indonesia adalah memberikan sanksi administrasi menurut peraturan yang berlaku. Macam-macam sanksi dalam Hukum Administrasi seperti berikut, paksaan pemerintahan (Bestuursdwang), penarikan kembali keputusan (ketetapan) yang menguntungkan, pengenaan denda administratif, dan pengenaan uang paksa oleh pemerintah (dwangsom). ${ }^{6}$

Berdasarkan macam-macam sanksi administrasi tersebut akan sulit diterapkan pada lini pelayanan publik khususnya pada pemerintahan yang notabenenya bentukan pemerintah juga. Apabila hendak dikenakan denda administrasi akan membuat suatu permasalahan baru karena tidak pernah ada penganggaran terhadap penggantian kerugian administrasi dan apabila itu diada-adakan bisa masuk hukum pidana dalam menindak karena sebagai bentuk tindak pidana korupsi. Sanksi mutasi terhadap pegawai bahkan pemecatan juga tidak akan mudah dilaksanakan.

Tantangan terbesar yang dihadapi oleh Ombudsman Republik Indonesia adalah mewujudkan kewenangannya secara efektif sehingga bisa menjadi lembaga negara yang memiliki andil sebagaimana dibebankan terhadapnya, yakni sebagai pengawal pelayanan publik. Semua lembaga negara memiliki tugas dan fungsi yang saling melengkapi sehingga tidak terjadi tumpang tindih kewenangan antar setiap lembaga negara. Berdasarkan Prinsip Trias Politica yang dibuat oleh Montesqeau, kekuasaan negara terbagi menjadi kekuasaan legislatif, eksekutif, dan yudikatif. ${ }^{7}$ Kekuasaan itu terbagi dalam rangka membuat suatu sistem pemerintahan yang saling mengawasi (checks and balances) sehingga tidak terjadi malpraktek terhadap tugas pokok dan fungsi sebuah lembaga negara.

Eksistensi lembaga legislatif, eksekutif, dan yudikatif dipengaruhi oleh lembaga-lembaga negara yang turut memberikan kekuatan pengawasan

\footnotetext{
${ }^{6}$ Diperoleh dari http://www.edipranoto.com/2011/05/sanksi-hukum-administrasi.html pada hari Kamis, 30 Oktober 20014 Pukul 06.00 WIB.

${ }^{7}$ Soehino, Ilmu Negara, (DI. Yogyakarta: Liberty Yogyakarta, 1998), hlm. 117.
} 
satu sama lain. Pada hakikatnya lembaga-lembaga negara ini berada sejajar dengan lembaga negara lainnya sehingga memiliki kekuatan yang sama dalam menjalani tugas dan fungsinya masing-masing.

Ombudsman pertama lahir di negara Eropa, yaitu Swedia. Ombudsman merupakan wujud ketidakpuasan masyarakat negara Swedia terhadap kondisi pelayanan publik sehingga mendesak negara Swedia melahirkan sebuah lembaga yang berwenang masuk kepada lembagalembaga pelayanan publik untuk mengkritisi dan mengawasi kinerja mereka dan menjadi bahan evaluasi terhadap lembaga tersebut. Semua permasalahan mengenai keberadaan lembaga ini dan permasalahan apa yang mendegradasi lembaga ini dalam menjalani tugas dan fungsinya merupakan masalah urgent yang ingin penulis kontemplasikan dalam sebuah tulisan berdasarkan semua latar belakang permalahan yang terurai di atas. ${ }^{8}$

\section{B. Pembahasan}

\section{Tugas Pokok dan Fungsi Ombudsman}

Sebuah lembaga negara dibuat dengan maksud untuk menjalankan suatu tugas dan fungsi tertentu. Semua tugas dan fungsi tersebut menjadi ukuran mengenai eksistensi lembaga negara tersebut di masyarakat. Sebuah kontemplasi mengenai lembaga yang didirikan namun tidak memiliki kontribusi konkret suatu hal yang perlu dilakukan karena sebuah lembaga memakan anggaran yang berasal dari anggaran belanja negara yang notabenenya dari dana masyarakat. Lembaga Ombudsman merupakan lembaga negara yang awalnya lahir dari sebuah transformasi paham negara hukum yang demokratis ke negara hukum yang bertanggung jawab. Transformasi ini terjadi disebabkan karena: ${ }^{10}$

a. untuk mengembangkan dirinya warga negara dan penduduk kini lebih tergantung pada pemerintah daripada sebelumnya;

b. selama abad ke-20 terjadi perkembangan dan pertumbuhan lembagalembaga birokrasi yang secara kolektif (secara lembaga) atau oleh pejabat atau aparatur pemerintah (secara individu) dapat menimbulkan ketidakseimbangan dalam hubungan antara warga negara yang lemah dan lembaga pemerintahan yang kuat, sehingga mudah terjadi penyalahgunaan wewenang oleh pemerintah terhadap warga masyarakat.

\footnotetext{
${ }^{8}$ Uraian lebih jelas baca Galang Asmara, Ombudsman Republik Indonesia, (Surabaya: Laksbang Yustitia, 2012), hlm, 9.

9 Tim Penyusun Buku Ombudsman Republik Indonesia, Ombudsprudensi, (Jakarta : Ombudsman Republik Indonesia, 2009), hlm. 13.

${ }^{10} \mathrm{Ibid}$.
} 
Sejarah Ombudsman Republik Indonesia adalah suatu langkah yang diambil Pemerintahan Abdul Rahman Wahid (alias Gusdur) bersama Megawati Soekarno Putri atas desakan masyarakat yang merasa pelayanan publik yang tidak transparan, bersih, dan bebas KKN. Lembaga Ombudsman ini tidak langsung terbentuk tetapi melalui berbagai proses yang cukup menguras pikiran karena terjadi banyak diskusi-diskusi yang dilakukan untuk menyusun konsep lembaga Ombudsman Republik Indonesia. Diawali dengan berbentuk komisi Ombudsman yang kemudian dilakukan studi mengenai hakikat pendirian lembaga Ombudsman di berbagai negara menjadi proses yang juga dijalani sebelum terbentuknya Lembaga Ombudsman. Studi di berbagai negara yang memiliki Lembaga Ombudsman ini dilakukan dengan tujuan untuk menggali dan memperdalam pengetahuan tentang apa dan bagaimana Ombudsman seharunya melakukan kerja-kerja pengawasan, dan apa saja prinsip-prinsip Ombudsman yang berlaku universal. Hingga pada tahun 2008 terbentuk Undang-Undang No. 37 Tahun 2008 tentang Ombudsman Republik Indonesia.

Tugas dari Lembaga Ombudsman adalah mengawal keberlangsungan pemerintahan supaya tetap pada koridor yang benar. Pemerintahan yang baik harus taat pada hukum dan norma yang ada sehingga pemerintahan yang ada akan memenuhi cita hukum dalam Undang-Undang No. 28 Tahun 1999 tentang Penyelenggaraan negara yang bersih dan Bebas KKN. Dalam Pasal 3 Undang-Undang tersebut disebutkan beberapa norma pemerintah yang baik, yaitu:

1. asas kepastian hukum;

2. asas keseimbangan;

3. asas kesamaan;

4. asas kecermatan;

5. asas motivasi;

6. asas tidak melampaui dan atau mencampuradukkan kewenangan;

7. asas nondiskriminasi;

8. asas keadilan;

9. asas kewajaran dan kepatutan;

10. asas menanggapi pengharapan yang wajar;

11. asas meniadakan akibat-akibat suatu keputusan yang batal;

12. asas-asas perlindungan atas pandangan hidup pribadi;

13. asas tertib penyelenggaraan administrasi pemerintahan;

14. asas keterbukaan;

15. asas proporsionalitas;

16. asas profesionalisme;

17. asas akuntabilitas;

18. asas kepentingan umum;

19. asas efisiensi; dan 
20. asas efektifitas;

Peran Lembaga Ombudsman juga untuk mendorong penyelenggaraan administrasi yang semakin baik. Asas-asas umum pemerintahan yang baik yang sebagian besar tercantum di atas menjadi tolok ukur untuk menilai sejauh mana aparat telah melakukan perbuatan maladministrasi. Dengan demikian, Lembaga Ombudsman dalam menjalankan tugas harus juga cepat, tidak berbelit-belit, gratis, dan bukan mengancam eksistensi lembaga lain melainkan memberikan rekomendasi yang membangun dan memperbaiki.

Peran lainnya dari Lembaga Ombudsman adalah untuk mewujudkan Good Govenance. Pemerintah seharusnya menjadi pelayan masyarakat yang memberikan kemudahan untuk mengembangkan kemampuan masyarakat dalam berbagai bidang. Pengawasan yang dilakukan oleh Lembaga Ombudsman memfokuskan diri pada pengawasan pemberian pelayanan umum sehingga penyelenggaraan pemerintahan sesuai dengan nilai-nilai kepatutan, penghormatan hak-hak dasar, keadilan serta moralitas. Berdasarkan hal tersebut Ombudsman yang dibentuk harus memiliki kewenangan secara independen sehingga dalam menjalankan tugas dan fungsinya akan bertindak secara objektif, adil, dan tidak berpihak. Hal ini sebagaimana tertuang dalam Pasal 2 Undang-Undang No. 37 Tahun 2008 tentang Ombudsman Republik Indonesia.

Berbicara mengenai kemandirian Ombudsman, Martin Oosting membagi sifat independensi Ombudsman menjadi independensi institusional, fungsional, dan personal. ${ }^{11}$ Independensi Institusional maksudnya, Ombudsman bukan bagian dari instansi publik manapun dan memiliki jabatan tinggi dalam sistem pemerintahan. Independensi fungsional maksdunya Ombudsman tidak dapat diintervensi ataupun dikendalikan oleh pengaruh penguasa manapun sehingga Ombudsman harus diberi wewenang yang luas disertai prosedur yang fleksibel (tidak kaku). Sedangkan independensi personal dimaksudkan para pegawai (sumber daya manusia) Ombudsman harus dari seleksi yang ketat dan akuntabel sehingga dapat bekerja dengan baik dan tidak tergoda pada pengaruh-pengaruh KKN (Korupsi, Kolusi, dan Nepotisme). Semua yang terurai di atas tersebut menjadi sebuah cita idealis dalam pembentukan Lembaga Ombudsman.

Berdasarkan Pasal 7 Undang-Undang No. 37 Tahun 2008 tentang Ombudsman Republik Indonesia, Ombudsman bertugas:

a. menerima laporan atas dugaan maladministrasi dalam penyelenggaraan pelayanan publik;

b. melakukan pemeriksaan substansi atas laporan;

c. menindaklanjuti laporan yang tercakup dalam ruang lingkup kewenangan Ombudsman;

\footnotetext{
${ }^{11}$ Tim Penyusun Buku Ombudsman Republik Indonesia, loc.cit., hlm. 42-43.
} 
d. melakukan investigasi atas prakarsa sendiri terhadap dugaan maladministrasi dalam penyelenggaraan pelayanan publik;

e. melakukan koordinasi dan kerja sama dengan lembaga negara atau lembaga pemerintahan lainnya serta lembaga kemasyarakatan dan perseorangan;

f. membangun jaringan kerja;

g. melakukan upaya pencegahan mal administrasi dalam penyelenggaraan pelayanan publik; dan

h. melakukan tugas lain yang diberikan oleh undang-undang.

Berdasarkan Pasal 8 Undang-Undang No. 37 Tahun 2008 tentang

Ombudsman Republik Indonesia, Ombudsman berwenang:

a. meminta keterangan secara lisan dan/atau tertulis dari pelapor, terlapor, atau pihak lain yang terkait mengenai laporan yang disampaikan kepada Ombudsman;

b. memeriksa keputusan, surat-menyurat, atau dokumen lain yang ada pada Pelapor ataupun Terlapor untuk mendapatkan kebenaran suatu Laporan;

c. meminta klarifikasi dan/atau salinan atau fotokopi dokumen yang diperlukan dari instansi mana pun untuk pemeriksaan laporan dari instansi terlapor;

d. melakukan pemanggilan terhadap pelapor, terlapor, dan pihak lain yang terkait dengan laporan;

e. menyelesaikan laporan melalui mediasi dan konsiliasi atas permintaan para pihak;

f. membuat rekomendasi mengenai penyelesaian laporan, termasuk rekomendasi untuk membayar ganti rugi dan/atau rehabilitasi kepada pihak yang dirugikan; dan

g. demi kepentingan umum mengumumkan hasil temuan, kesimpulan, dan rekomendasi.

Selain wewenang sebagaimana dimaksud pada ayat (1), Pasal 8 di atas Ombudsman juga berwenang:

a. menyampaikan saran kepada presiden, kepala daerah, atau pimpinan penyelenggara negara lainnya guna perbaikan dan penyempurnaan organisasi dan/atau prosedur pelayanan publik;

b. menyampaikan saran kepada Dewan Perwakilan Rakyat dan/atau Presiden, Dewan Perwakilan Rakyat Daerah dan/atau kepala daerah agar terhadap undang-undang dan peraturan perundang-undangan lainnya diadakan perubahan dalam rangka mencegah maladministrasi.

Semua tugas dan fungsi yang diberikan oleh Undang-Undang Ombudsman tersebut dibayar mahal oleh bangsa ini semata-mata untuk menciptakan pengawasan terhadap pelayanan publik yang optimal. Idealisme yang ada pada diri para punggawa pendiri Ombudsman Republik Indonesia perlu diapresiasi dan dilestarikan melalui penguatan terhadap 
Lembaga Ombudsman tersebut. Ombudsman apabila dicermati didirikan sebagai salah satu wujud pemenuhan cita-cita bangsa Indonesia yang terdapat pada alinea ke-4 Pembukaan UUD NRI Tahun 1945, yaitu:

1. melindungi segenap bangsa Indonesia dan seluruh tumpah darah Indonesia;

2. memajukan kesejahteraan umun;

3. mencerdaskan kehidupan bangsa; dan

4. ikut melaksanakan ketertiban dunia yang berdasarkan kemerdekaan, perdamaian abadi, dan keadilan sosial.

Ombudsman memiliki tugas dan fungsi melindungi hak-hak masyarakat terhadap perbuatan maladministrasi yang dilakukan oleh lembaga publik yang hal tersebut merupakan sebagai bentuk memajukan kesejahteraan umum. Ombudsman juga dalam menjalankan tugas memberikan advokasi-advokasi terhadap hak dan kewajiban sebagai warga negara dihadapan pemerintah sehingga mendidik masyarakat untuk tidak acuh tak acuh terhadap pelanggaran melainkan berani melawan dengan melaporkan kepada Ombudsman.

Dengan demikian sudah sepatutnya undang-undang yang mengatur Ombudsman juga harus mewadahi semua tujuan idealis bangsa Indonesia tersebut agar eksistensi Ombudsman sebagaimana yang dicitakan tersebut tidak ada yang dilanggar.

Undang-undang merupakan produk politik sehingga sangat rentan dengan penyimpangan yang akhirnya menghalangi spirit awal dari penciptaan undang-undang tersebut. Undang-undang lain yang ada juga harus memperkuat eksistensi suatu undang-undang bukan justru mendegradasi suatu undang-undang. Oleh karena itu setiap undang-undang memiliki suatu norma dasar (grundnorm) yang menjadi embrio dari setiap undang-undang. Norma dasar bangsa Indonesia adalah Pancasila yang merupakan manifestasi bangsa dari segala kemajemukan yang ada. Pancasila menjadi tujuan politik hukum nasional yang digunakan sebagai saran menciptakan suatu sistem hukum nasional dan cita-cita (tujuan) bangsa Indonesia. ${ }^{12}$

Pada undang-undang Ombudsman yang sudah ada sudah cukup mengakomodir tugas dan fungsi Ombudsman di Indonesia pada hakikatnya. Tugas pokok dan fungsi yang dimiliki oleh Ombudsman sebenarnya apabila diterapkan secara efektif mudah-mudahan dapat membentuk pengawasan terhadap pelayanan publik yang optimal. Hal tersebut didukung juga dengan diundangkannya Undang-Undang yang mengatur khusus mengenai pelayanan publik. Diundangkannya Undang-Undang No. 25 Tahun 2009

\footnotetext{
12 Imam Syaukani dan A Ahsin, Dasar-Dasar Politik Hukum, (Jakarta: PT Raja Grafindo Persada, 2004), hlm 59.
} 
tentang Pelayanan Publik menambah kekuatan bagi Ombudsman dalam menjalankan tugas dan fungsinya.

Undang-Undang Pelayanan publik mempertegas serta memperjelas fungsi, tugas, serta kedudukan Ombudsman Republik Indonesia sebagai berikut: ${ }^{13}$

a. dalam Undang-Undang Ombudsman Republik Indonesia ketentuan mengenai makna pelayanan publik padahal Ombudsman mengemban tugas melakukan pengawasan terhadap penyelenggaraan pelayanan publik. Dalam Undang-Undang Pelayanan Publik, pengaturan mengenai pengertian pelayanan publik makna diatur dalam Pasal 1 angka 1 Undang-Undang pelayanan publik tersebut; dan

b. mengenai tempat kedudukan Ombudsman dalam Undang-Undang Ombudsman RI disebutkan: Ombudsman dapat mendirikan Perwakilan di Provinsi dan/atau Kabupaten/Kota vide Pasal 5 ayat (2) sedangkan Undang-Undang Pelayanan Publik melalui Pasal 46 ayat $(3,4,7)$ menetapkan secara lebih tegas:

1) Ombudsman wajib membentuk perwakilan di daerah yang bersifat hierarkis untuk mendukung tugas dan fungsi ombudsman di dalam pelayanan publik;

2) pembentukan perwakilan publik ombudsman di daerah dilakukan paling lambat 3 (tiga) tahun sejak Undang-Undang pelayanan publik diundangkan; dan

3) penyelesaian pengaduan oleh Ombudsman dapat dilakukan oleh Perwakilan Ombudsman di daerah.

Selain hal yang di atas Undang-Undang pelayanan publik juga lebih memperkuat fungsi, tugas, dan kewenangan Ombudsman berdasarkan poinpoin tersebut: ${ }^{14}$

a. pasal 18 huruf g menyatakan masyarakat berhak mengadukan pelaksana yang melakukan penyimpangan standar pelayanan dan/atau tidak memperbaiki pelayanan kepada Ombudsman;

b. pasal 18 huruf $\mathrm{h}$ menyatakan masyarakat berhak mengadukan penyelenggara yang melakukan penyimpangan standar pelayanan dan/atau tidak memperbaiki pelayanan kepada Ombudsman;

c. pasal 35 ayat (3) huruf b: pengawasan eksternal penyelenggaraan pelayanan publik dilakukan melalui pengawasan oleh Ombudsman sesuai dengan peraturan perundang-undangan;

d. pasal 36 ayat (2): penyelenggara berkewajiban mengelola pengaduan yang berasal dari rekomendasi Ombudsman;

\footnotetext{
${ }^{13}$ Tim Penyusun Buku Ombudsman Republik Indonesia, loc.cit. hlm. 36.

${ }^{14}$ Ibid. hlm. 36-37
} 
e. pasal 40 ayat (1) masyarakat berhak mengadukan penyelenggaraan pelayanan publik kepada Ombudsman.

f. pasal 46 ayat (7) mekanisme dan tata cara penyelesaian pengaduan oleh Ombudsman diatur lebih lanjut dalam Peraturan Ombudsman;

g. Pasal 50 ayat (7) mekanisme dan tata cara pelaksanaan ajudikasi khusus oleh Ombudsman diatur lebih lanjut dalam Peraturan Ombudsman;

h. Pasal 52 ayat (2) pengajuan gugatan terhadap penyelenggara tidak menghapus kewajiban penyelenggara untuk melaksanakan keputusan Ombudsman; dan

i. pasal 53 ayat (2) laporan pidana terhadap penyelenggara tidak menghapus kewajiban penyelenggara untuk melaksanakan keputusan Ombudsman.

Kewenangan Ombudsman Republik Indonesia juga ditambah berdasarkan Undang-Undang pelayanan publik, yaitu:

a. pasal 8 ayat (1) huruf e UU ORI menyatakan Ombudsman berwenang menyelesaikan laporan melalui mediasi dan konsiliasi atas permintaan para pihak, sedangkan Pasal 50 ayat (5) Undang-Undang Pelayanan Publik menyatakan dalam hal penyelesaian ganti rugi Ombudsman dapat melakukan mediasi, konsiliasi, dan ajudikasi khusus. Pasal 1 angka 11 menyatakan bahwa ajudikasi adalah proses penyelesaian sengketa pelayanan publik antar pihak yang diputus oleh Ombudsman; dan

b. dalam Undang-Undang No. 37 Tahun 2008 Pasal 18 ayat (1) huruf f menyebutkan Ombudsman membuat rekomendasi untuk membayar ganti rugi dan/atau rehabilitasi kepada pihak yang dirugikan. Juga dalam Pasal 39 menyatakan Terlapor dan atasan Terlapor yang melanggar kewajiban melaksanakan rekomendasi Ombudsman dikenai sanksi administrasi. Sementara itu undang-undang Pelayanan Publik menyatakan khususnya mengenai ketentuan sanksi menyebut adanya sanksi pembekuan misi dan/atau izin yang diterbitkan oleh instansi pemerintah, serta pencabutan izin yang diterbitkan oleh instansi pemerintah.

Berdasarkan semua penambahan dan penguatan tugas pokok dan fungsi serta kewenangan Lembaga Ombudsman Republik Indonesia yang terurai di atas membuktikan bahwa sudah baiknya pengaturan mengenai Ombudsman di Indonesia. Permasalahan mengenai keberadaan Ombudsman di Indonesia yang masih belum efektif menurut penulis bukan berasal dari regulasi yang mengaturnya melainkan ada permasalahan lainnya. Sebagaimana terurai dalam latar belakang tulisan ini dijelaskan masih ada satu lagi permasalahan yang mendegradasi eksistensi dari Lembaga Ombudsman ini dalam menjalankan tugas pokok dan fungsinya (TUPOKSI). 


\section{Permasalahan Lembaga Ombudsman dalam Menjalankan TUPOKSI}

Keberadaan Ombudsman Republik Indonesia merupakan bagian dari saran pembaharuan (Agent of Change), yang berperan dalam mengubah kebiasaan lama yang mana masyarakat harus mengabdi kepada pejabat menjadi pejabat negara yang harus mengabdi kepada masyarakat. ${ }^{15}$ Ombudsman sebagai alat kelengkapan negara dalam mencapai tujuan kesejahteraan dan keamanan di masyarakat.

Keberadaan Ombudsman tidak hanya ada di pusat, melainkan juga di daerah khususnya di ibukota Provinsi. Hal ini terkait dengan semangat otonomi daerah yang berupaya mendekatkan pelayanan pemerintah terhadap yang diperintah sesuai dengan amanat UU No. 23 tahun 2014 tentang pemerintah daerah.

Sorotan tajam masyarakat banyak ditujukan pada model pelayanan pemerintah di daerah yang kurang optimal. Dengan adanya Ombudsman di daerah diharapkan dapat melakukan pola perubahan kebiasaan yang dilayani menjadi melayani. Tujuannya adalah untuk menekan praktek KKN (Korupsi, Kolusi, dan Nepotisme) di daerah sehingga daerah sebagai ujung tombak utama pelayanan pemerintah pusat kepada rakyat dapat terwujud.

Adanya perubahan pada penyelenggaraan negara tersebut bertujuan pada perubahan proses dan prosedur, norma-norma hukum dan budaya, tuntutan keahlian dan kemahiran serta komitmen sumber daya manusia, yang pada akhirnya juga akan membawa perubahan pada penganggaran (budgetting), penggajian, bahkan juga pada struktur organisasi sistem birokrasi itu sendiri. Menurut Weber berdasarkan pengertian organisasi, sebagai berikut ${ }^{16}$ :

"Organization is the corporate aspect of social life, the capacity for collective action"

Dengan demikian organisasi melakukan suatu penyelenggaraan program kerja supaya efektif harus sesuai dengan berbagai aspek-aspek kehidupan. Berdasarkan hal tersebut Ombudsman dalam hal ini diumpamakan sebagai suatu organisasi juga harus melakukan programprogram pengawasan terhadap pelayanan publik harus sesuai dengan aspekaspek pelayanan publik sehingga adanya asas-asas penyelenggaran pemerintahan yang baik sebagai acuannya. Konsep penyelenggaraan pemerintahan yang baik tersebut sebagai wujud perubahan kebiasaan lama secara sistemik di pemerintahan khususnya dalam hal pelayanan publik.

Konsep perubahan tersebut di Indonesia baru terjadi pada akhir tahun 2000. Pejabat pemerintahan yang ter-mindset untuk tidak bekerja dengan

\footnotetext{
${ }^{15}$ Ibid. hlm. 72.

${ }^{16}$ Weber dalam Donald Black, loc.cit. hlm. 85.
} 
kualitas melainkan sebagai bentuk pemenuhan tuntutan pekerjaan menjadi suatu masalah yang sudah sistemik di Indonesia. Banyak Pejabat pemerintahan dan pegawai negeri yang mengklaim bahwa lembaga/ institusinya sudah mengalami reformasi birokrasi tetapi masih berdasarkan pandangan atau visi dan norma yang lama. Ombudsman sebagai harapan baru melakukan perubahan mindset tersebut secara bertahap dan meyakinkan mencoba menawarkan perubahan.

Visi mencoba mereformasi pejabat dan aparat birokrasi dan Penegak Hukum, termasuk peradilan untuk mengubah cara pandang dan cara kerjanya agar melakukan tugasnya secara lebih cepat, lebih profesional tanpa mengingat biaya tambahan (suap dan korupsi), secara tidak berpihak, terbuka, dan adil. Visi yang diemban tersebut masih belum terasa dampaknya secara signifikan hingga sekarang. Lalu timbul pertanyaan bagaimana Ombudsman yang dibuat secara baik dan dengan aturan khusus dan pendukung yang lengkap masih belum berjalan efektif juga.

Menurut penulis Ombudsman yang merupakan lembaga baru tetapi masih memiliki sumber daya manusia yang memiliki visi yang lama. Perlu dibangun kesadaran moril dari lembaga Ombudsman ini. Khususnya bagi aparat Ombudsman di daerah. Di mana minimnya sumber daya manusia di daerah juga berpengaruh pada kinerjanya.

Langkahnya dapat melalui rekutmen pegawai Ombudsman yang kompetitif dan adanya pengetesan psikologis yang menguji etos dan ketulusan calon pegawai dalam bekerja. Apabila hal ini masih belum terlaksana secara demikian niscaya visi baru yang ditawarkan Ombudsman disertai sistem kerja lama juga tetap akan berjalan menuju pada visi yang lama juga.

Perlu digarisbawahi bahwa Lembaga Ombudsman merupakan lembaga yang akan dibanjiri dengan keluhan-keluhan seperti laporan kepada polisi yang tidak ditindaklanjuti, pembuatan sertifikat tanah yang lambat di BPN, dan lain sebagainya. Bagaimana mungkin melihat permasalahan tersebut masih juga Ombudsman belum mewujudkan perubahan yang radikal sebagaimana diakomodir oleh Undang-Undang. Berdasarkan hal tersebut Ombudsman harus memperbaiki pegawainya dan bertindak tegas terhadap pegawai yang tidak bertanggung jawab. Itulah langkah sosiologis dari dalam lembaga yang harus pertama kali diterapkan. Setelah itu Ombudsman akan dapat melaksanakan investigasi secara sistemik hingga ke akar masalah dari suatu lembaga pelayanan publik yang melakukan tindakan mal administrasi.

Ombudsman Republik Indonesia bukan merupakan lembaga sementara, tetapi sudah menjadi lembaga permanen di mana merupakan pilar keempat penyempurnaan dari konsep Montesque (legislatif, eksekutif, dan 
yudikatif) yakni pilar pengawasan. ${ }^{17}$ Pilar pengawasan ini menjadi penguat sistem checks and balances di Indonesia.

Sehingga jangan sampai ekspektasi yang tinggi oleh masyarakat terhadap perubahan pola kinerja lembaga pemerintahan runtuh akibat kinerja pegawai Ombudsman di daerah yang rendah. Sebagai perbandingan Ombudsman di DIY-Jateng diperoleh data berkait laporan masyarakat yang masuk ke Ombudsman adalah: tahun 2004 (22), 2005 (197), 2006 (197), 2006 (170), 2007 (223), 2008 (213), 2009 (247), dan 2010 (172). ${ }^{18}$ Sedangkan untuk di Provinsi Lampung sepanjang 2013 Ombudsman Lampung telah menangani 120 perkara ${ }^{19}$.

\section{Penutup}

1. Kesimpulan

a. Ombudsman merupakan lembaga negara yang diciptakan sebagai pengawal pelayanan publik dan diakomodir dengan undang-undang khusus dan undang-undang pendukung lainnya. Dengan demikian, tidak perlu diragukan eksistensi secara kasat mata. Lembaga ini sebagai alat kelengkapan negara dalam mencapai tujuan kesejahteraan dan keamanan di masyarakat karena mencegah adanya kepastiaan masyarakat terhadap pemerintahan dan memberikan advokasi masyarakat dalam memenuhi hak dan kewajibannya.

b. Dalam rangka memenuhi visi tersebut diperlukan suatu perubahan konsep penyelenggaraan negara juga, yaitu terbuka, efisien, efektif,dan terbebas dari praktek KKN (Korupsi, Kolusi, dan Nepotisme). Dengan adanya perubahan pada penyelenggaraan negara tersebut bertujuan pada perubahan proses dan prosedur, norma-norma hukum dan budaya, tuntutan keahlian dan kemahiran serta komitmen sumber daya manusia, yang pada akhirnya juga akan membawa perubahan pada penganggaran (budgetting), penggajian, bahkan juga pada struktur organisasi sistem

${ }^{17}$ Tim Penyusun Buku Ombudsman Republik Indonesia, loc.cit. hlm. 75.

18 Dyah Adriantini Sintha Dewi, Politik Hukum Kebijakan Pembentukan Ombudsman Sebagai Lembaga Pengawasan Eksternal, Jurnal Konstitusi Universitas Muhammadiyah Magelang,Vol.II No.1, September 2013, hlm.47

19 Adapun hasil penelitian kepatuhan pemda terhadap UU pelayanan Publik yang diselenggarakan pada Bulan Oktober hingga November 2013 yang lalu menunjukan bahwa sebanyak $80 \%$ atau 16 SKPD di Provinsi Lampung dan 77\% atau 20 SKPD di Kota Bandar Lampung masuk dalam zona merah yang berarti rendah tingkat kepatuhannya dalam pelaksanaan UU 25 Tahun 2009 tentang Pelayanan Publik. 15\% atau 3 SKPD di Provinsi Lampung dan $15 \%$ atau 4 SKPD di Kota Bandar Lampung masuk kedalam zona kuning atau zona tengah, yang berarti sedang tingkat kepatuhannya. Dan 5\% atau 1 SKPD di Provinsi Lampung dan Dan 8\% atau 2 SKPD di Bandar Lampung masuk dalam zona hijau yang berarti tinggi tingkat kepatuhannya. Sumber http://lampost.co/berita/2013ombudsman-lampung-terima-120-pengaduan 
birokrasi itu sendiri. Ada pepatah yang menyatakan "jika ingin membersihkan sesuatu harus dengan alat pembersih yang bersih, karena jika yang digunakan kotor juga itu adalah hal yang sia-sia”.

\section{Saran}

a. Berdasarkan hal tersebut birokrasi reformasi harus dilakukan dari dalam diri Ombudsman terlebih dahulu sehingga reformasi birokrasi yang dicitakan bukan hanya wacana semata;

b. Diperlukan sosialisasi terus menerus tidak hanya oleh lembaga ombudsman saja melainkan juga segenap pemangku kebijakan untuk selalu melakukan dan memberikan pelayanan publik yang maksimal.

\section{Daftar Pustaka}

\section{A. Buku}

Asmara, Galang, 2012. Ombudsman Republik Indonesia, Surabaya: Laksbang Yustitia.

Asshiddiqie, Jimly, 2012. Perkembangan dan Konsolidasi Lembaga Pasca Reformasi, Jakarta: Sinar Grafika.

Black, Donald, 1976. The Behavior of Law, London : Academic Press.

Lutfi, Mustafa, dan M. Iwan Satriawan, 2014, Meneropong Komisi Informasi Publik, Malang: UB Press.

Neta, Yulia, dan M. Iwan Satriawan, 2013, Ilmu Negara, Bandar Lampung: PK-PUU FH UNILA.

Soehino, 1998, Ilmu Negara, DI Yogyakarta : Liberty Yogyakarta.

Syaukani, Imam, dan A. Ahsin, 2004, Dasar-Dasar Politik Hukum, Jakarta: PT Raja Grafindo Persada.

Tim Penyusun Buku Ombudsman Republik Indonesia, Ombudsprudensi, Jakarta: Ombudsman.

\section{B. Jurnal}

Dyah Adriantini Sintha Dewi, Politik Hukum Kebijakan Pembentukan Ombudsman Sebagai Lembaga Pengawasan Eksternal, Jurnal Konstitusi Univ. Muhammadiyah Magelang, Vol II No. 1 tahun 2013.

\section{Undang-Undang}

UUD 1945

Undang-Undang No. 37 Tahun 2008 tentang Ombudsman Republik Indonesia 
Undang-Undang No. 25 Tahun 2009 tentang Pelayanan Publik

\section{Internet}

http://www.edipranoto.com/2011/05/sanksi-hukum-administrasi.html pada hari Kamis, 30 Oktober 2014 Pukul 06.00 WIB. 